\title{
Lung Function in Combined Pulmonary Fibrosis and Emphysema Syndrome, What to Expect
}

\author{
Jolanda Nikolla ${ }^{1 *}$, Hasan Hafizi $^{2}$, Roland Hasa ${ }^{3}$ \\ ${ }^{1}$ Department of Internal Medicine, American Hospital, Albania \\ ${ }^{2}$ Department of Pulmonology, UH "Shefqet Ndroqi", Albania \\ ${ }^{3}$ Department of Radiology, UH "Shefqet Ndroqi", Albania
}

Submission: June 07, 2017; Published: July 26, 2017

*Corresponding author: Jolanda Nikolla, Department of Internal Medicine, Pulmonologist, Subdivision Pulmonology, American Hospital 3, Tirana, Albania, Tel: + 3556922 47312; Email: jnikolla@yahoo.com

Abstract

Introduction: Combined Pulmonary Fibrosis and Emphysema Syndrome (CPFE) is a distinct entity and has been identified as such recently. In contrast with Dlco reduced lung function is preserved in these patients.

Objective: Our aimed was to study the differences in the lung function, demographic and clinical data of CPFE syndrome versus IPF patients.

Materials and Methods: We studied retrospectively the medical records of the patients with interstitial lung diseases during the time period 2012 - 2016. The diagnosis was based on HRCT findings based on ATS/ERS criteria the lung function, demographic and clinical data were collected. EVIEWS 7 and SPSS programs were used for statistical study. Mean values and standard deviation were used for normal variables. Student test and Pearson Correlation Coefficient were used for numerical variables and for evaluating the existence and their importance in correlations. $P$ values less than 0.05 were statistically significant.

Results: In total 53 (100\%) subjects with ILD.27 (50.9\%) CPFE patients and 25 (49.1\%). Compared to IPF in CPFE group pre-dominated male's current smokers or ex smokers and the mean age was higher (67.29 \pm 6.87 ). Lung volumes were closer to normal values in CPFE patients. Dlco was lower in this group (47.9 \pm 16$)$. PAH was more frequent too $(42.8 \%)$. There was an important and positive statistical correlation between Dlco and CPI ( $\mathrm{r}=-0.7, \mathrm{p}=0.003)$.

Conclusion: CPFE syndrome is frequent. Its diagnosis should be earlier. There are differences in CPFE syndrome and IPF patients mainly in lung function parameters.

Keywords: Lung function; Combined pulmonary fibrosis and emphysema syndrome

Abbreviations: ILD: Interstitial Lung Diseases; IPF: Idiopathic Pulmonary Fibrosis; CPFE: Combined Pulmonary Fibrosis and Emphysema

\section{Introduction}

Interstitial lung diseases (ILD) are a large and heterogeneous group of lung clinical entities. Among them idiopathic pulmonary fibrosis (IPF) is the most frequent [1]. The coexistence of pulmonary emphysema and IPF in the same patient is recently recognized as a distinct syndrome titled "Combined Pulmonary Fibrosis and Emphysema" (CPFE), by Cottin et al. [1-3]. Smoking and connective tissue diseases are the most encountered etiologic factors causing IPF and CPFE syndrome. The clinical, functional and radiological status of these patients has important differences compared to them of IPF only [3]. Demographics features of CPFE and IPF are nearly similar but smoking history is longer and heavier in CPFE group. In particular there is distinction in lung function presentation [1-3]. CPFE patients have higher lung volumes (FEV1- forced expiratory volume of the first second, FVC- forced vital capacity, FEV1/FVC ratio in $\%)$ lower values of diffusion lung capacity for carbon monoxide (Dlco), more profound hypoxemia and lower values of oxygen saturation in arterial blood (Sat $02 \%$ ). Pulmonary arterial hypertension (PAH) also has higher prevalence in CPFE patients. It is encountered earlier in CPFE than IPF, however it represents a significant prognostic factor for mortality in both pathologies [1-5] (Figure 1). 


\section{PAH in CPFE vs IPF}

\begin{tabular}{|c|c|c|c|c|c|c|}
\hline \multicolumn{2}{|l|}{ แே } & \multicolumn{4}{|c|}{32} & \\
\hline \multirow{5}{*}{ 岌 } & & \multirow{2}{*}{12} & \multirow{3}{*}{20} & & \multirow[t]{2}{*}{428.} & \\
\hline & & & & & & \\
\hline & 0 & 10 & & 3 & 40 & 50 \\
\hline & \multicolumn{2}{|c|}{ CPFEtotal } & & \multicolumn{2}{|c|}{ IPF total } & \\
\hline & N & $\%$ & & $N$ & $\%$ & \\
\hline$\because \mathrm{PAH}$ & 12 & 42.8 & & 8 & 32 & \\
\hline
\end{tabular}

Figure 1: The frequency of PAH in large groups.

\section{Materials and Methods}

This study is approved by Ethics Committees of the University of Tirana, and the University Hospital "Shefqet Ndroqi", in Tirana, Albania where the work has been undertaken. This is a retrospective cohort study of the time period 2012-2016.

\section{Subjects}

53 patients in total were enrolled in the study. They were all diagnosed with ILD based on American Thoracic Society/ European Respiratory Society (ATS/ERS) guidelines [6,7]. We have collected the demographics, clinical, lung function and high-resolution computed tomographic (HRCT) data of the patients from their medical records. The HRCT scans findings were evaluated from two different radiologists independently from each other and without having any knowledge about the clinical picture of the patients.

HRCT criteria for diagnosis of CPFE syndrome [3-7] were as follows:

- $\quad$ The presence of bi-apical lung emphysema and/or multiple bullae ( $>1 \mathrm{~cm}$ diameter) AND

- $\quad$ The presence of significant bilateral lung fibrosis with peripheral and basal predominance, with/without traction bronchiectasis and with/without honey combing.

After discussions we had selected the patients in two large groups: 28 CPFE patients and 25 IPF patients.

\section{Inclusion criteria}

The patients with the following characteristics were included in the study:

- $\quad$ Patients aged $\geq 50$ years

- $\quad$ Patients who had a chest HRCT scan result

- $\quad$ Patients with a Spirometry and/or Dlco test result

- Patients who had a cardiac ultrasound performed

- Patients with arterial blood gases (ABG) result performed.

\section{Exclusion criteria}

The patients with the following characteristics were excluded from the study:

- $\quad$ Patients aged $<50$ years

- $\quad$ Patients diagnosed with drug-associated ILD

- $\quad$ Patient diagnosed with occupational related ILD

According to the etiologic factors [4] the two large groups are divided further in subgroups as follows: CPFE group is divided in: 1.Idiopathic CPFE (smoking) 2.CPFE in connective tissue diseases (CPFE-CTD).IPF group is divided in: 1.Idiopathic IPF (smoking) 2.IPF in connective tissue diseases (IPF-CTD). Concerning smoking, patients are classified as: never smokers, ex-smokers and current smokers. For evaluating smoking status we have used Unit Pack Year formula: UPY = (number of cigarettes smoked per day/20) x number of years smoked. For evaluating dyspnea status we have used m MRC (the modified Medical Research Council) score and the patients were classified as having dyspnea one of scores I, II, III or IV [8]. Dlco test was performed from not all the patients due to the severe conditions of them. The composite physiological index (CPI) was calculated according to the formula: The extent of the fibrosis in $\mathrm{CT}=91.0$ - (0.65 x predicted of DLCO \%) - (0.53 x predicted of FVC \%) $+(0.34 \times \%$ predicted of FEV1 \%). The GAP (gender, age and physiology) index and the mortality risk scoring system was calculated too. PAH was diagnosed as having resting SPSAP $\geq 25$ $\mathrm{mm} \mathrm{Hg}$ or in effort sPSAP $\geq 30 \mathrm{~mm} \mathrm{Hg}$ values [9-11].

\section{Statistical analysis}

For statistical analyses were used EVIEWS 7 and SPSS version 20 (SPSS-Statistical Package for Social Sciences Inc., Chicago, IL, USA) programs. Demographics, clinical and lung functional data are expressed in mean values and standard deviation \pm SD. For testing numerical and independent categorical variables is used Student test. Pearson Correlation Coefficient is used for numerical variables for evaluating the existence and their importance in correlations. Hypotheses were tested using disfactorial linear regression. Logistic binary regression was used for evaluating the correlations between the variables. $P$ values less than 0.05 were accepted as statistically significant.

\section{Results}

The percentage of CPFE in our group was high (50.9\%). Table 1 shows more specifically the distribution of the most important demographics and clinical data of the subgroups. In total 53 patients (100\%). From them 45.3\% idiopathic CPFE patients, $41.5 \%$ idiopathic IPF, 7.5\% CPFE-CTD and 5.7\% IPFCTD. The mean age of the patients was higher idiopathic CPFE $(67.29 \pm 6.87)$. Males predominated in three first subgroups, $70.8 \%, 54.5 \%$ and $50 \%$ respectively. Current smokers or exsmokers males were also the most of the subgroups. UPY values were higher in idiopathic CPFE $(28.4 \pm 13.2)$ and CPFE-CTD $(23.7 \pm 13.8)$ subgroups. $50 \%$ of Idiopathic CPFE had mMRC III 
dyspnea score. Finger clubbing was more frequent in idiopathic IPF subgroup (13.6\%). Table 2 shows the lung function parameters in subgroups. It was evident that CPFE subgroups had lower mean values of predicted FVC \% and FEV1 compared to IPF subgroups.FEV1/FVC ratio \% mean values tended to be more close to the normal ranges $(90 \pm 22.7)$ in idiopathic CPFE subgroup. Mean values of Sat $02 \%$ and $\mathrm{PaO} 2$ were lower in idiopathic CPFE compared to other subgroups. Dlco mean values were lower in idiopathic CPFE subgroup $(47.9 \pm 16)$ and the majority of the patient (83.4\% idiopathic CPFE subgroup) had high mortality rate in the second year of the diseases (Table

Table 1: Demographics and clinical data in subgroups.

\begin{tabular}{|l|l|}
\hline & Idiopathic CPFE N \\
\hline
\end{tabular}

\begin{tabular}{|c|c|c|} 
& $\begin{array}{c}\text { Idiopathic CPFE N } \\
\mathbf{2} \mathbf{2 4}\end{array}$ & $\begin{array}{c}\text { Idiopathic IPF N } \\
\mathbf{2} 22\end{array}$ \\
\hline Variables & Mean \pm SD & Mean \pm SD \\
\hline
\end{tabular}

\begin{tabular}{|c|c|c|}
\hline Age (years) & $67.29( \pm 6.87)$ & $61.18( \pm 7.73)$ \\
\hline Gender M/F & $70.8 \%$ / 29.2\% & $54.5 \% / 45.5 \%$ \\
\hline
\end{tabular}

\begin{tabular}{|c|c|c|}
\hline Gender M/F & $70.8 \% / 29.2 \%$ & $54.5 \% / 45.5 \%$ \\
\hline $\mathrm{BMI} \mathrm{kg} / \mathrm{m}^{2}$ & $29.24( \pm 5.03)$ & $28.94( \pm 4.37)$ \\
\hline
\end{tabular}

3). PAH was more frequent in the large group of CPFE (42.8\%) and mean SPSAP values were higher too in this group $(42.4 \pm 3.4)$

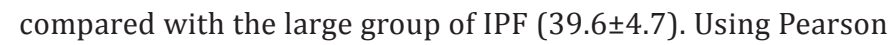
test were analyzed if there were any correlation of DLco with the lung function variables such as $\mathrm{CPI}, \mathrm{FVC}, \mathrm{FEV} 1, \mathrm{PaO}_{2}$ and was also evaluated the importance of Dlco especially in CPFE patients, (Figure 2a-2e). There was an important and positive statistical correlation between Dlco and CPI $(r=-0.7 p=0.003)$, the other variables did not have important correlations with Dlco, (Table 4).

\begin{tabular}{|c|c|c|c|c|c|}
\hline Smoking status & $\mathrm{M} / \mathrm{F}$ & $\mathrm{M} / \mathrm{F}$ & $\mathrm{M} / \mathrm{F}$ & $\mathrm{M} / \mathrm{F}$ & 0.0175 \\
\hline Never & $0 \% / 29.2 \%$ & $4.54 \% / 45.4 \%$ & $0 \% / 50 \%$ & $0 \% / 33.4 \%$ & \\
\hline Ex-smokers & $33.3 \% / 0 \%$ & $18.18 \% / 4.54 \%$ & $25 \% / 0 \%$ & $0 \% / 66.6 \%$ & \\
\hline Current smokers & $37.5 \%$ / $0 \%$ & $22.7 \%$ / 4.54\% & $25 \% / 0 \%$ & $0 \% / 0 \%$ & \\
\hline UPY p/y & $28.4 \pm 13.2$ & $21.25 \pm 15$ & $23.7 \pm 13.8$ & $15 \pm 4.7$ & 0.0156 \\
\hline Dyspnea & $100 \%$ & $100 \%$ & $100 \%$ & $100 \%$ & 0.0003 \\
\hline I mMRC & $4.20 \%$ & $4.50 \%$ & $0 \%$ & $0 \%$ & \\
\hline II & $29.10 \%$ & $36.40 \%$ & $50 \%$ & $0 \%$ & \\
\hline III & $50 \%$ & $36.40 \%$ & $25 \%$ & $100 \%$ & \\
\hline IV & $16.70 \%$ & $27.70 \%$ & $25 \%$ & $0 \%$ & \\
\hline Clubbing & $4.20 \%$ & $13.60 \%$ & $0 \%$ & $0 \%$ & 0.04324 \\
\hline
\end{tabular}

Table 2: Lung function data in subgroups.

\begin{tabular}{|c|c|c|c|}
\hline Idiopathic CPFE N = 24 & Idiopathic IPF N = 22 & CPFE - CTD N = 4 & IPF - CTD N = 3 \\
\hline Variables & Mean \pm SD & Mean \pm SD & Mean \pm SD \pm SD \\
\hline predicted FVC \% & $64 \pm 15$ & $67 \pm 12$ & $68 \pm 5$ \\
\hline predicted FEV1 \% & $57 \pm 17$ & $65.5 \pm 17$ & $58 \pm 15$ \\
\hline FEV1/FVC ratio \% & $90 \pm 22.7$ & $97 \pm 15$ & $104 \pm 14$ \\
\hline
\end{tabular}




\section{International Journal of Pulmonary \& Respiratory Sciences}

\begin{tabular}{|c|c|c|c|c|}
\hline Sat $02 \%$ & $88 \pm 9.9$ & $89 \pm 6.3$ & $90 \pm 1$ & $93 \pm 2$ \\
\hline $\mathrm{PaO} 2 \mathrm{kPa}$ & $66.4 \pm 13.3$ & $69 \pm 8.9$ & $67.5 \pm 7.3$ & $68.6 \pm 8$ \\
\hline
\end{tabular}

Table 3: Lung function data in subgroups.

\begin{tabular}{|c|c|c|c|c|}
\hline & Idiopathic CPFE N = 6 & Idiopathic IPF N =7 & CPFE-CTD N $=4$ & IPF-CTD N $=3$ \\
\hline Variables & Mean \pm SD & Mean \pm SD & Mean \pm SD & Mean \pm SD \\
\hline predicted Dlco \% & $47.9 \pm 16$ & $48.1 \pm 11.1$ & $45.7 \pm 6.9$ & $46.3 \pm 7.6$ \\
\hline CPI & $46.1 \pm 9.3$ & $47.4 \pm 6.6$ & $49.3 \pm 6.9$ & $47 \pm 15.8$ \\
\hline GAP & $4.6 \pm 1.03$ & $3.4 \pm 1.3$ & $4 \pm 0.8$ & $5.6 \pm 0.5$ \\
\hline \multicolumn{5}{|l|}{ Stage } \\
\hline I & $0 \%$ & $28.50 \%$ & $25 \%$ & $0 \%$ \\
\hline II & $83.40 \%$ & $71.50 \%$ & $75 \%$ & $66.60 \%$ \\
\hline III & $16.60 \%$ & $0 \%$ & $0 \%$ & $33.40 \%$ \\
\hline \multicolumn{5}{|l|}{ Mortality } \\
\hline 1 year & $0 \%$ & $28.50 \%$ & $25 \%$ & $0 \%$ \\
\hline 2 year & $83.40 \%$ & $71.50 \%$ & $75 \%$ & $66.60 \%$ \\
\hline 3 year & $16.60 \%$ & $0 \%$ & $0 \%$ & $33.40 \%$ \\
\hline
\end{tabular}

Table 4: Correlations of DIco and CPI, FVC, FEV1, $\mathrm{PaO}_{2}$, CPFE.

\begin{tabular}{|c|c|c|c|c|}
\hline Dlco & & & & \\
\hline \\
Variables & $\mathrm{r}$ & $\mathrm{p}$ & $95 \% \mathrm{CI}$ \\
\hline CPI & -0.72 & 0.003 & -0.26 & -0.137 \\
\hline FVC & -0.161 & 0.498 & -0.428 & -0.216 \\
\hline FEV1 & -0.056 & 0.814 & -0.216 & -0.113 \\
\hline PaO2 & 0.024 & 0.921 & 0.221 & 0.42 \\
\hline CPFE & 0.143 & 0.548 & 0.08 & 0.17 \\
\hline
\end{tabular}



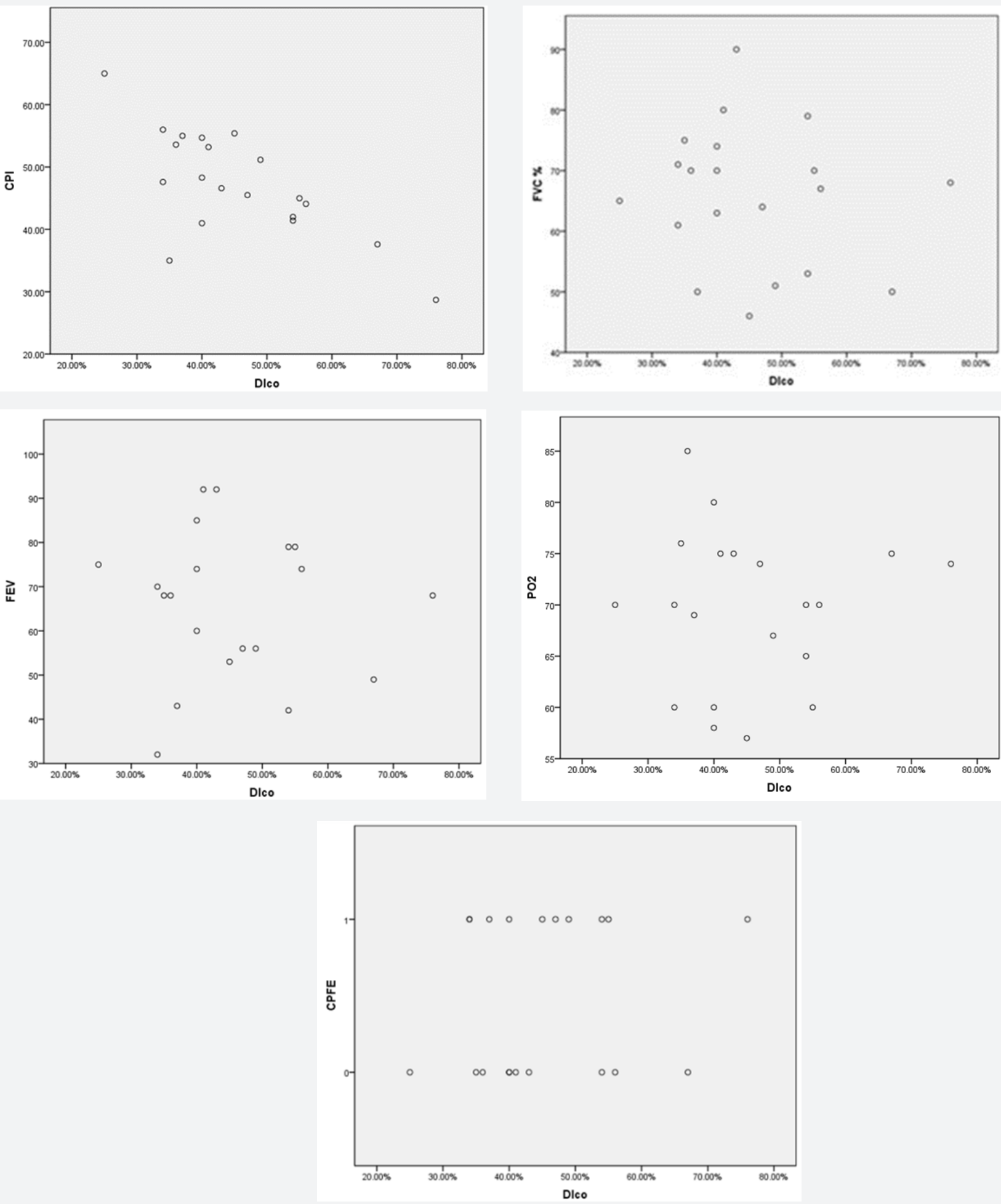

Figure 2a-2e: The correlation graphs of Dlco and CPI, FVC, FEV1, $\mathrm{PaO}_{2}$ and CPFE respectively.

\section{Discussion}

The presence of emphysema in IPF patients (CPFE syndrome) is $21-33 \%$ based in recently literature [1,2]. In our study it was higher $50.9 \%$. We had males' smokers or ex-smokers with high values of UPY and in older age too. Lung volumes in CPFE patients were close to normal values. Dlco values were more compromised in CPFE patients. Our group of CPFE patients had higher values of SPAP as it is prescribed in published papers 
$[11,12]$. We did not find important correlations among Dlco and the other lung function parameters in our study population. We should also emphasize that our study had limitations such as the relatively small number of the patients; it was a retrospective study and the information was taken from medical records so that some data might be lost. However lung function in our group of CPFE had differences compared to IPF patients group

\section{Conclusion}

Patients with CPFE syndrome have different lung function picture than IPF patients but they are underestimated. Usually they are grouped with IPF patients. We should be more prudent on diagnosing earlier these patients given the fact that this syndrome is not rare anymore.

\section{References}

1. Cottin V, Cordier JF (2009) The syndrome of combined pulmonary fibrosis and emphysema. Chest 136(1): 1-2.

2. Jankowich MD, Rounds SIS (2012) Combined pulmonary fibrosis and emphysema syndrome: A review. Chest 141(1): 222-231.

3. Raghu G, Collard HR, Egan J, Martinez FJ, Behr J, et al. (2011) An official ATS/ERS/JRS/ALAT statement: Idiopathic pulmonary fibrosis: evidence-based guidelines for diagnosis and management. Am J Respir Crit Care Med 183(6): 788-824.

4. Cottin V, Cordier JF, Richeldi L (2015) Orphan Lung Diseases: A Clinical Guide to Rare Lung Disease. Springer-Verlag, London, UK, pp. 327.
5. Vij R, Noth I, Strek ME (2011) Autoimmune-featured interstitial lung disease:a distinct entity. Chest 140(5): 1292-1299.

6. (2000) American Thoracic Society. Idiopathic pulmonary fibrosis: diagnosis and treatment. International consensus statement. American Thoracic Society (ATS), and the European Respiratory Society (ERS). Am J Respir Crit Care Med 161(2 pt 1): 646-664.

7. (2002) American Thoracic Society/European Respiratory Society International multidisciplinary consensus classification of the idiopathic interstitial pneumonias. Am J Respir Crit Care Med 165(2): 277-304.

8. Jastrzebski D, Gumola A, Gawlik R, Kozielski J (2006) Dyspnea and quality of life in patients with pulmonary fibrosis after six weeks of respiratory rehabilitation. J Physiol Pharmacol 57(Suppl 4): 139-148.

9. Kolb M, Collard H (2014) Staging of idiopathic pulmonary fibrosis: past, present and future. European Respiratory. Review 23(132): 220224.

10. Nathan SD, Shlobin OA, Ahmad S, Urbanek S, Barnett SD (2007) Pulmonary hypertension and pulmonary function testing in idiopathic pulmonary fibrosis. Chest 131(3): 657-663.

11. Cottin V, Le Pavec J, Prevot G, Mal H, Humbert M, et al. (2010) Pulmonary hypertension in patients with combined pulmonary fibrosis and emphysema syndrome. Eur Respir J 35(1): 105-111.

12. Cottin V, Cordier JF (2012) Combined pulmonary fibrosis and emphysema in connective tissue disease. Curr Opin Pulm Med 18(5): 418-427.

Your next submission with Juniper Publishers will reach you the below assets

- Quality Editorial service

- Swift Peer Review

- Reprints availability

- E-prints Service

- Manuscript Podcast for convenient understanding

- Global attainment for your research

- Manuscript accessibility in different formats

( Pdf, E-pub, Full Text, Audio)

- Unceasing customer service

Track the below URL for one-step submission https://juniperpublishers.com/online-submission.php 